\title{
Laparoscopic surgery of interstitial (cornual) pregnancy, a case report
}

\author{
intertisyel (kornual) gebeliğin laparoskopik tedavisi, vaka sunumu \\ Ziya Günenç ${ }^{1}$, Banu Bingöl' ${ }^{2}$ Aygen Çelik ${ }^{1}$, Serpil Bozkurt ${ }^{1}$, Ümit Özekici ${ }^{1}$ \\ 'Department of Obstetrics and Gynecology, Maltepe University, Istanbul, Turkey \\ ${ }^{2}$ Department of Obstetrics and Gynecology, Bilim University Gayrettepe Florence Nightingale Hospital, Istanbul, Turkey
}

\section{Abstract}

We report a successful laparoscopic management of an interstitial pregnancy of a 24- year-old single woman, treated by cornuostomy. The patient was first managed with methotrexate treatment. After the 2. methotrexate administration, the patient suffered from low abdominal pain, and intraabdominal bleeding signs were reported by transvaginal ultrasonograpy. The hemoglobin level was decreased from $12.8 \mathrm{gr} / \mathrm{dl}$ to $11.8 \mathrm{gr} / \mathrm{dl}$ and the beta hCG level was increased from 8,314 $\mathrm{mIU} / \mathrm{l}$ to $11,541 \mathrm{mIU} / \mathrm{l}$. The laparoscopic approach to interstitial pregnancy was presented and other management strategies such as medical treatment and laparotomy have been reviewed.

(J Turkish-German Gynecol Assoc 2010; 11: 102-4)

Key words: Interstitial (cornual) pregnancy, laparoscopy, methotrexate, cornuostomy

Received: 24 June, 2009

Accepted: 17 September, 2009
Özet

24 yaşında bekar bir bayan hastada görülen intertisyel (kornual) ektopik gebelik vakasının laparoskopik kornuostomi uygulanarak, başarılı bir şekilde tedavisi sunulmuştur. Tanı konulmasını takiben; önce metotreksat tedavisine alınan hastada, 2. metotreksat uygulaması sonrası gelişen kasık ağrısı şikayeti nedeniyle yapılan transvajinal ultrasonografide, intraabdominal kanama bulguları görülmüştür. Hemoglobin seviyesinin $12.8 \mathrm{gr} / \mathrm{dl}$ 'den $11.8 \mathrm{gr} / \mathrm{dl}$ 'ye düşmesi ve beta hCG düzeyinin $8,314 \mathrm{mIU} / \mathrm{ml}$ 'den 11,541 mIU/ml'ye yükselmesi üzerine, hasta laparoskopiye alınmıştır. Bu makalede intertisyel gebeliklerde laparoskopik uygulamalar ve diğer tedavi seçenekleri (medikal tedavi ve laparotomi) irdelenmiştir.

(J Turkish-German Gynecol Assoc 2010; 11: 102-4)

Anahtar kelimeler: İntertisyel (kornual) gebelik, laparoskopi, metotreksat, kornuostomi

Geliş Tarihi: 24 Haziran 2009

Kabul Tarihi: 17 Eylül 2009

\section{Introduction}

Interstitial pregnancy is a rare form of ectopic pregnancy that can lead to catastrophic events. As the cornua are the vascular confluence region, a ruptured cornu can trigger a life-threatening hemorrhage and may lead to rupture of the uterus in a subsequent pregnancy (1). It comprises $2 \%$ of all ectopic pregnancies (2). The gold standard was to treat interstitial pregnancy by laparotomy with cornual resection, but sometimes difficult hemostasis needs hysterectomy or hypogastric artery ligation to be performed. Current trends in treatment are mostly conservative with the objective of minimizing morbidity and preserving fertility. These conservative methods may be medical or surgical, such as intramuscular methotrexate administration (3), local injection of methotrexate or potassium chloride (4) with or without systemic, multidose methotrexate (5), laparoscopic cornuotomy using a temporary tourniquet suture and diluted vasopressin injection (6). The terms cornual and interstitial pregnancy are used synonymously to define pregnancy implanted in the interstitial part of the fallopian tube which is the proximal portion that is embodied within the muscular wall of the uterus. We present our case to raise awareness of this rare pathology which has a different diagnosis and to highlight the recent advances in fertility preserving treatments.

\section{Case report}

A 24-year-old woman Gravida:3, Para:0 with 2 artificial abortions was admitted to our hospital with 6 weeks of amenorrhea, spotting and lower abdominal pain. On examination, her internal os was closed and she had tenderness in the left fornix. The uterus was hypertrophic, and there was a little vaginal bleeding. Transvaginal ultrasonography scan showed a heterogeneous mass of $3 \mathrm{~cm}$ which has a $14 \mathrm{~mm}$ gestational sac situated in the left cornual region. The endometrial thickness was $14 \mathrm{~mm}$, no fetal pole or yolk sac was seen. The endometrial biopsy using abdominal ultrasonography guidance showed that the gestational sac was not interfering with endometrial cavity and the material did not have chorionic villi. The beta hCG level was $8314 \mathrm{mIU} / \mathrm{ml}$, hemoglobin ( $\mathrm{Hb})$ level was $12.8 \mathrm{gr} / \mathrm{dl}$, and the patient was hemodynamically stable. We administered the first dose of methotrexate (1 mg/ $\mathrm{kg})$ and folinic asid $(0.1 \mathrm{mg} / \mathrm{kg})$ therapy. On the third day after 
the second methotrexate therapy, the patient suffered from lower abdominal pain. A transvaginal ultrasonography revealed fluid in the Douglas pouch, and the myometrial thickness was as thin as $3 \mathrm{~mm}$ in the left cornual region. The laboratory results were as follows; Hb: $11.8 \mathrm{gr} / \mathrm{dl}$, beta hCG: 11,541 mIU/ml. A laparoscopy that immediately followed revealed the presence of an enlarged left cornua (Figure 1), and intraabdominal bleeding (from the tubal ostium). A successful laparoscopic cornuostomy operation was performed.

\section{Surgical technique}

After endotracheal intubation and general anesthesia in a dorsolithotomy position, a Veress needle was inserted through the umbilicus, and the abdomen was inflated with CO2. In the laparoscopic exploration, the left enlarged cornua was seen. Bipolar coagulation was performed on the cornual region as far away as possible from the tube. Monopolar cauterisation was used to make a vertical incision. The gestational sac was emptied with grasping forceps and suction irrigation under the magnified view provided by the laparoscope. Again, bipolar coagulation was used for the hemostasis. After hemostasis, the cornua was stitched with Vicryl sutures using the intracorporeal technique (Figure 2). Strict hemostasis and hemoperitoneal evacuation were performed and a Hemovac drain was inserted into the abdominal cavity, which was expelled after 12 hours. The serum beta-hCG level returned to within normal range approximately 5 weeks postoperatively.

\section{Discussion}

The incidence of interstitial ectopic pregnancy is $2.8 \%$ of all ectopic pregnancies and 1 in 2035 live births (7). Early diagnosis is the most important part of the management and outcome of the patients. With the advances in high-resolution transvaginal ultrasonography and the sensitive beta-hCG assay, it is now

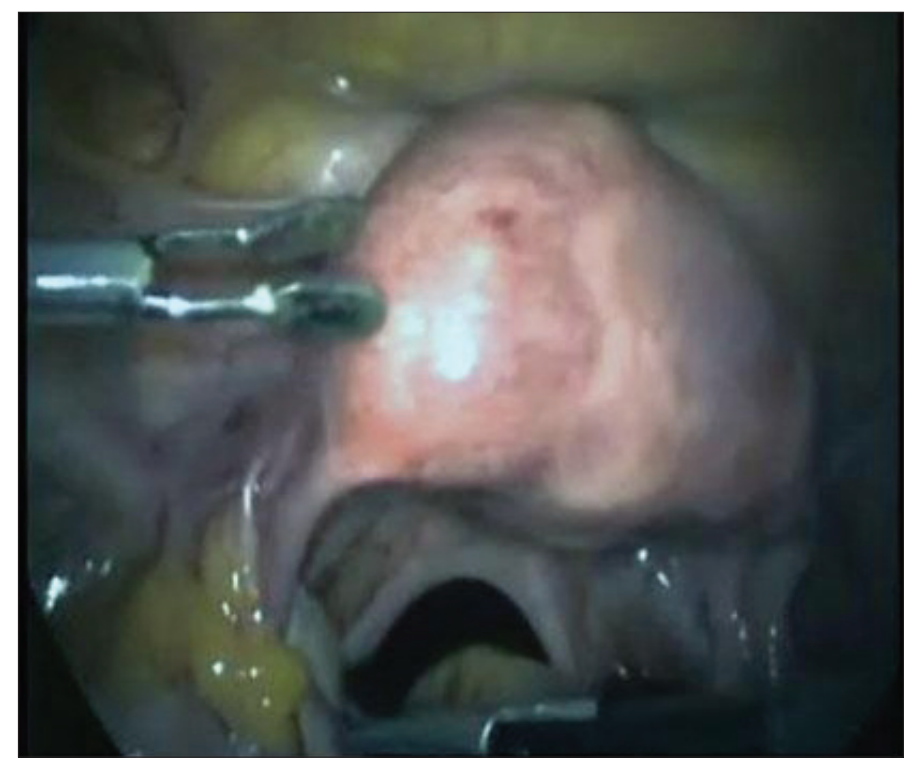

Figure 1. Cornual (interstitial) pregnancy before laparoscopy possible to diagnose interstitial pregnancy at an earlier time. The cornual mass is the most common ultrasound scan finding in the definitive diagnosis of a cornual (interstitial) pregnancy. Timor-Tritsch et al. (8) described three diagnostic criteria for cornual pregnancy: 1) an empty uterine cavity, 2) a chorionic sac seen separately and $>1 \mathrm{~cm}$ from the most lateral edge of the uterine cavity, 3) a thin myometrial layer surrounding the gestational sac. Our patient's findings were consistent with all the criteria reported above. The traditional treatment of interstitial pregnancy was hysterectomy or cornual resection by laparotomy. Today to the experience of most of the gynecological operations can be performed laparoscopically. In experienced hands Laparoscopic techniques involve cornual resection, cornuostomy.

The most important point in laparoscopic cornual operations is fertility preserving surgery and hemostasis. During hemostasis, we prefer to use bipolar coagulation by using saline solution to maintain electrolytes in the operative field. Also, if bipolar coagulation was not enough for hemostasis, we used monopolar coagulation in the cutting mode with 30-40 watts. Monopolar coagulation with high voltage and coagulation mode can result in myometrial end endometrial damage, which may affect future conceptions. Hemostasis may also be achieved with vasopressin but because the vascularization is high, it may pass to the systemic circulation in a very short time; and therefore the dose must be controlled. Laparoscopic suturing techniques are also very important in these operations. We prefer to perform a figure of eight with vicryl suture by using intracorporeal suturing technique.

Most authors will concur that the size of the cornual pregnancy determines the best laparoscopic approach. Tulandi et al. (9) reported that cornuostomy is appropriate for gestations $<3.5$ $\mathrm{cm}$, whereas Grobman and Milad (10) recommended cornual wedge resection for gestation $>4 \mathrm{~cm}$. In our case the dimension of the cornual gestation was about $3 \mathrm{~cm}$. In some cases,

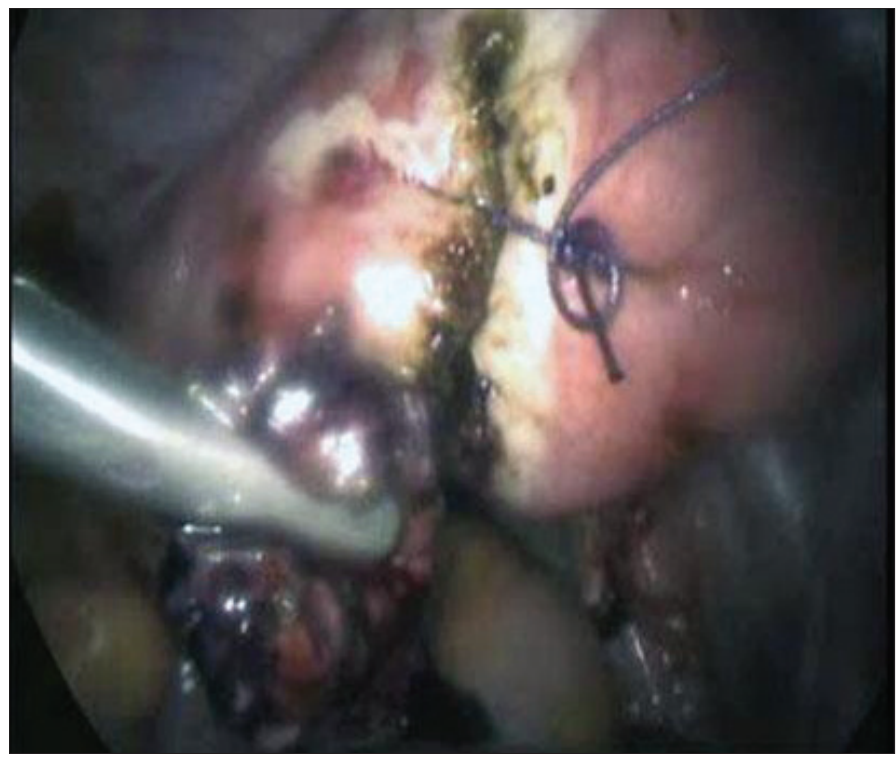

Figure 2. The intraabdomial view after laparoscopy 
post-surgical methotrexate treatment or guided potassium chloride injection to the amniotic sac is needed to succeed in termination of the pregnancy (4).

In conclusion, interstitial (cornual) pregnancy remains a challenging and dangerous pathology, and early diagnosis and treatment is paramount. The treatment choice depends on various parameters; laparoscopy allows the diagnosis and treatment together. When managing an interstitial pregnancy, experience of the surgeon plays an important role. The surgeon must be competent in suturing and coagulation techniques. In experienced hands, laparoscopy is a safe and effective treatment for interstitial pregnancy.

\section{Conflict of interest}

None declared

\section{References}

1. Damario MA, Rock JA. Te-Linde's operative gynecology. 9th ed. Philadelphia: Lippincott- Williams\&Wilkins, 2003: 507-33.

2. Bren JL. A 21 year survey of 654 ectopic pregnancies. Am J Obstet Gynecol 1970; 106: 1004-19.
3. Barnhart K, Spandorfer S, Coutifaris C. Medical treatment of interstitial pregnancy. A report of three unsuccessful cases. J Reprod Med. 1997; 42: 521-4.

4. Benifla JL, Fernandez H, Sebban E, Darai E, Frydman R, Madelenat P. Alternative to surgery of treatment of unruptured interstitial pregnancy: 15 cases of medical treatment. Eur J Obstet Gynecol Reprod Biol. 1996; 70: 151-6.

5. Hajenius PJ, Voigt RR, Engelsbel S, Mol BW, Hemrika DJ, Van der Veen F. Serum human chorionic gonadotropin clearance curves in patients with interstitial pregnancy treated with systemic methotrexate. Fertil Steril. 1996; 66: 723-8.

6. Choi YS, Eun DS, Choi J, Shin KS, Choi JH, Park HD. Laparoscopic cornuotomy using a temporary tourniquet suture and diluted vasopressin injection in interstitial pregnancy. Fertil Steril. 2009; 91: 1933-7.

7. MacRae R, Olowu O, Rizzuto MI, Odejinmi F. Diagnosis and laparoscopic management of 11 consecutive cases of cornual ectopic pregnancy. Arch Gynecol Obstet. 2009; 280: 59-64.

8. Timor-Tritsch IE, Monteagudo A, Matera C, Veit CR. Sonographic evolution of cornual pregnancies treated without surgery. Obstet Gynecol. 1992; 79: 1044-9.

9. Tulandi T, Vilos G, Gomel V. Laparoscopic treatment of interstitial pregnancy. Obstet Gynecol. 1995; 85: 465-7.

10. Grobman WA, Milad MP. Conservative laparoscopic management of a large cornual ectopic pregnancy. Hum Reprod. 1998; 13: 20024. PubMed PMID: 9740466.

\section{CONGRESS CALENDAR}

27-30 June 2010 ESHRE, Rome, Italy

http://www.eshre.com

30 June-2 July 2010 Gynecological Endoscopy Education Days, Izmir-Turkey

www.egelaparoskopi.org

25-29 September 2010 12. Gynecological Oncology Congress, Antalya, Turkey www.jineonko2010.org

26-29 September 2010 7th National Congress of Turkish Maternal Fetal Medicine and Perinatology Association, Istanbul, Turkey www.tmftpkongre2010.org

2-5 October 2010 ESIDOG, Trieste, Italy www.esidogtrieste.eu

7-10 October 2010 4th National Congress on Reproductive Endocrinology and Infertility, TSRM 2010, Antalya, Turkey www.tsrm.org.tr

23-27 October 2010 ASRM, Denver, Colorado, USA http://www.asrm.org

27-31 October 2010 7th Congress of Obstetric and Gynecological Ultrasound, Harbiye Military Museum, İstanbul, Turkey www.usgkongre2010.org

6-10 April 2011 AAGL 5th International Congress on Minimally Invasive Gynecology, Istanbul, Turkey www.tsge2011.org

4-8 May 2011 9th Congress of the Turkish-German Gynecology Foundation, Antalya, Turkey www.tajev.org

25-29 May 2011 19th International Pelvic Pain Society Annual Scientific Meeting, Istanbul, Turkey www.ipps2011.org 